\title{
Organ State
}

National Cancer Institute

\section{Source}

National Cancer Institute. Organ State. NCI Thesaurus. Code C135508.

A condition or state of an organ at a particular time. 